\title{
Zintegrowane plany rozwoju - w stronę terytorialno-funkcjonalnego podejścia do rozwoju jednostki terytorialnej
}

\section{Terytorializacja procesów rozwoju - wprowadzenie}

Od początku lat dziewięćdziesiątych, w podejściu do kształtowania rozwoju lokalnego/regionalnego obserwujemy ewolucje wcześniejszego zainteresowania aglomeracją i nowymi przestrzeniami przemysłowymi na rzecz zagadnień oscylujących wokół problematyki sieci, specyficznych zasobów czy endogenicznego podejścia do rozwoju. Jest to między innymi konsekwencją przesunięcia akcentu $\mathrm{z}$ badań relacji input-output i powiązań materialnych w kierunku zagadnień poświęconych społecznym i instytucjonalnym aspektom rozwoju. Ta nowa orientacja badań eksponuje znaczenie czynników niematerialnych i terytorialnych, trudno ,uchwytnych" w analizach rozwoju społeczno-gospodarczego. Podkreśla ważność pozaekonomicznych czynników, takich jak: zaufanie, partnerstwo, instytucje, tradycje i tożsamość czy powiązania i relacje sieciowe.

Redefinicji czynników rozwoju towarzyszy wzrost zainteresowania lokalnym i regionalnym wymiarem rozwoju, który staje się fundamentalną skalą ekonomicznej i politycznej organizacji życia społeczno-gospodarczego. Z jednej strony lokalne/regionalne zasoby i mechanizmy stają się kluczem do zrozumienia współczesnego charakteru procesów rozwoju, z drugiej zaś lokalna/regionalna płaszczyzna podstawową skalą prowadzenia polityki rozwoju.

Równolegle następuje reinterpretacja pojęcia region i rozwoju regionalnego na rzecz pojęcia terytorium i rozwoju terytorialnego. W klasycznych teoriach

* Uniwersytet Łódzki, Wydział Ekonomiczno-Socjologiczny, Instytut Gospodarki Przestrzennej, Katedra Gospodarki Regionalnej i Środowiska, 90-214 Łódź, Rewolucji 1905 r. nr 39. 
rozwoju przestrzeń była wtórnym czynnikiem i statycznym miejscem lokalizacji podmiotów gospodarczych. Postrzegana była głównie jako przestrzeń fizyczna, definiowana przez pryzmat lokalizacji zasobów, kosztów prowadzenia działalności gospodarczej, lokalizacji siły roboczej czy kosztów transportu. Nowe podejście teoretyczne radykalnie odmiennie interpretuje znaczenie przestrzeni w procesach rozwoju. Terytorium określane jest przez pryzmat relacji i aktywność lokalnych aktorów oraz kapitał społeczny i instytucjonalny. Terytorium jest źródłem wielu niematerialnych zasobów, takich jak: informacja, wiedza, innowacja. Jest ono miejscem tworzenia się zasobów oraz zdolności rozwojowych podmiotów (Nowakowska, 2011).

W terytorialnym paradygmacie rozwoju, terytorium jest przestrzenią ukszta1towaną historycznie, w której powstał specyficzny układ instytucjonalno-organizacyjny. Kategoria terytorium wykracza poza proste rozumienie przestrzeni w wymiarze fizycznym i definiowana jest jako przestrzeń „stworzona” (fr. construit) przez określoną społeczność, mająca swoją historię i kulturę, nagromadzoną wiedzę i umiejętności wraz z funkcjonującymi w jej łonie instytucjami oraz sieciami relacji między wszystkimi aktorami życia społeczno-gospodarczego (Pietrzyk, 2004, s. 12-13). Terytorium nie jest przestrzenią określaną wielkością zgromadzonych zasobów czy granicami administracyjnymi, lecz przestrzenią określaną przez relacje i powiązania oraz wspólne mechanizmy rozwoju. Jest to przestrzeń stworzona poprzez naturalne powiązania społeczne i gospodarcze, tworzone przez podmioty posiadające wspólny cel działania (Pecqueur, 2005, s. 132). Innymi słowy terytorium definiowane jest przez pryzmat specyficznych i endogenicznych zasobów powstałych w sposób ewolucyjny, jest swoistym zasobem gospodarczym posiadającym swoją historię, kulturę, swoją logikę i architekturę społeczną. Terytorium jest więc określane przez posiadane zasoby i sposoby organizacji, jest to przede wszystkim „wytwór” podmiotów połączonych wspólnym celem działania (Jewtuchowicz, 2005).

W nowym paradygmacie rozwoju wyodrębniamy trzy główne wymiary terytorium: geograficzny, relacyjny oraz instytucjonalny (rys. 1). Te dwie ostatnie formy przestrzeni tworzą ,zawartość” terytorium, jego specyficzność i tożsamość. Są fundamentem dla tworzenia i funkcjonowania terytorium (Pietrzyk, 2004, s. 13).

Wymiar geograficzny terytorium wynika z lokalizacji i dostępu do zasobów tkwiących w konkretnym terytorium. Nie są to tylko powszechne i klasyczne zasoby, takie jak dostępność do infrastruktury technicznej i społecznej, jakość życia czy potencjał naukowo-badawczy zlokalizowany w danym terytorium. Nade wszystko kluczowe znaczenie odgrywają zasoby specyficzne i niepowtarzalne, tworzące unikalność danego terytorium i jego naturalną przewagę konkurencyjną. W tym kontekście, terytorium jest miejscem wspólnego i ewolucyjnego tworzenia zasobów i podmiotów, kumulacji informacji i wiedzy, źródłem procesów innowacji i sukcesu gospodarczego poszczególnych podmiotów. 


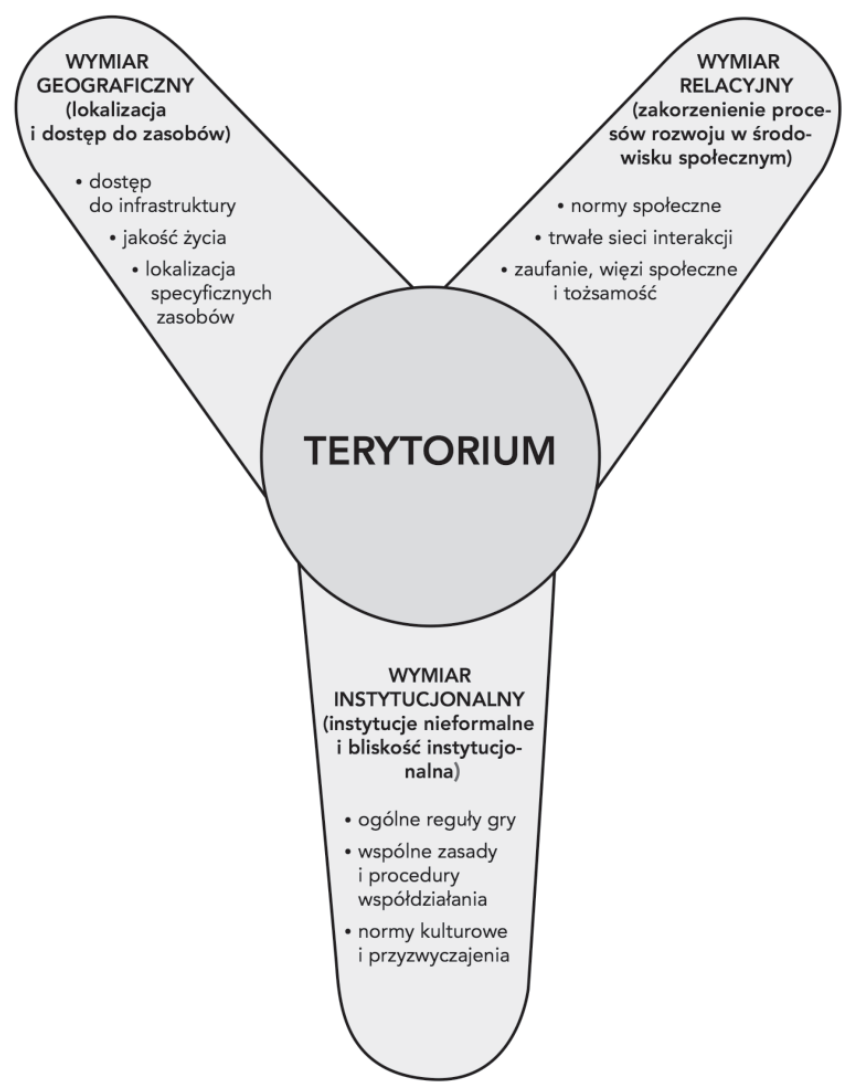

Rysunek 1. Geograficzny, relacyjny i instytucjonalny wymiar terytorium

Źródło: opracowanie własne

Wymiar relacyjny terytorialnego paradygmatu rozwoju opisuje zjawisko zakorzeniania procesów rozwoju, które określane jest mianem społecznego umocowania aktywności gospodarczej (Grzeszczak, 1999, s. 56-58). Jest to osadzenie działalności ekonomicznej i jej efektów w środowisku społecznym oraz wyjaśnienie społeczno-przestrzennej natury procesów gospodarczych. Wskazuje, że relacje pomiędzy podmiotami gospodarczymi są mocno zakorzenione w społecznym środowisku lokalnym, współzależą od określonej struktury terytorialnej i panujących tam norm, zaufania, relacji społecznych. $Z$ tej perspektywy terytorium charakteryzowane jest przez trwała sieć wzajemnych interakcji, tworzonych wspólnie przez daną społeczność, w której zaufanie, więzi i tożsamość, poczucie przynależności do danej społeczności (tzw. kapitał społeczny, często określany mianem kapitału relacyjnego) tworzą bazę dla działania podmiotów współtworzących terytorium. W podejściu terytorialnym przestrzeń zawiera element społecznego środowiska, gdzie jej aktorzy są wzajemnie połączeni wartościami ekonomicznymi, kulturowymi i historycznymi (Jewtuchowicz, 2005). 
Wymiar instytucjonalny pokazuje sposób organizacji terytorium oraz sposoby koordynacji zachowań podmiotów w nim funkcjonujących. Odwołuje się on do instytucji nieformalnych i bliskości instytucjonalnej (analizowanej w ramach nurtu nowej ekonomii instytucjonalnej). Instytucje nieformalne definiowane są jako zbiór wspólnych reguł gry, tworzonych przez wspólne zwyczaje, zasady i procedury współdziałania, regulują stosunki i interakcje pomiędzy podmiotami. Instytucje te tworzą bazę dla koordynacji działań gospodarczych, sprzyjając wymianie informacji, procesom kooperacji, interaktywnego i kolektywnego uczenia się. Instytucje funkcjonują jako rodzaj „kleju” dla wspólnych działań, zmniejszając niepewność i obniżając koszty transakcji (Boschma, 2005, s. 68). Instytucje formalne tworzone są zazwyczaj na poziomie ponadlokalnym (zasady prawne) i nie mają terytorialnego charakteru. Instytucje nieformalne są mocno zlokalizowane i powiązane z terytorium (np. normy kulturowe, przyzwyczajenia). Poziom bliskości instytucjonalnej warunkuje zakres i sposób, w jaki podmioty czy organizacje koordynują swoje zachowania rynkowe.

Rozwój terytorialny to rozwój przebiegający w układach funkcjonalnych, silnie powiązany zasobami specyficznymi i endogenicznymi. Jest to proces zorientowany na optymalne wykorzystanie kapitału terytorialnego, wspólnie tworzonego poprzez relacje sieciowe. Mocno warunkowany jest on kontekstem historycznym, społecznym i instytucjonalnym.

\section{Place-based policy - w kierunku terytorializacji i integracji polityki rozwoju}

\subsection{Idea place-based policy}

Nowa interpretacja znaczenia przestrzeni w procesach rozwoju gospodarczego stała się podstawą do reinterpretacji sposobów prowadzenia polityki rozwoju lokalnego/regionalnego. U podstaw nowego paradygmatu kształtowania polityki rozwoju leży także krytyka dotychczasowych metod stymulowania rozwoju dokonana u progu nowego okresu programowania. Kluczowe znaczenie miał tu raport F. Barca wskazujący na nieefektywność i nieskuteczność polityki kohezyjnej tak w wymiarze budowania spójności, jak i konkurencyjności europejskiej wspólnoty (Barca, 2009). Krytyka dotyczyła przede wszystkim zunifikowanej polityki regionalnej, nieuwzględniającej specyfiki miejsca oraz braku koordynacji i integracji działań podejmowanych przez różne podmioty publiczne. W odpowiedzi na te problemy podjęto próbę reform sposobów i narzędzi stymulowania rozwoju w wymiarze europejskim, regionalnym i lokalnym, których ucieleśnieniem jest paradygmat terytorialnej polityki rozwoju (ang. place based policy). 
Nowe podejście terytorialne ma na celu większe uwzględnienie zróżnicowanych uwarunkowań rozwoju oraz optymalne wykorzystanie endogenicznych zasobów (tzw. kapitałów terytorialnych) w dynamizacji procesów rozwoju (Camagni, 2011, s. 62-64). W szczególności postulowane jest:

1. Przewartościowanie czynników rozwoju, eksponowanie zróżnicowania i różnorodności zasobów jako źródła rozwoju społeczno-gospodarczego;

2. Orientacja polityki na wzmacnianie wewnętrznych i zewnętrznych powiązań funkcjonalnych na rzecz zwiększenia spójności terytorialnej;

3. Zwiększenie mobilizacji podmiotów lokalnych/regionalnych oraz dialogu społecznego i partnerstwa publiczno-prywatnego w działaniach na rzecz rozwoju terytorialnego;

4. Budowanie partnerstwa instytucjonalnego i integracja oddziaływania podmiotów publicznych (podmiotowa i sektorowa integracja polityki, identyfikacja i realizacja wspólnych celów rozwoju);

5. Terytorialne zróżnicowanie polityki rozwoju - odejście od uniwersalnego modelu polityki na rzecz polityki zróżnicowanej, w zależności od specyficznych zasobów, problemów i mechanizmów rozwoju terytorialnego (Nowakowska, 2013).

W terytorialno-funkcjonalnym podejściu, główne postulaty i wyzwania wobec działań władz publicznych w ramach polityki dotyczą zarówno obszarów oddziaływania, jak i sposobów kształtowania interwencji publicznej (metod i instrumentów zarządzania). Główne filary nowej polityki rozwoju ogniskują się wokół trzech obszarów (Territorial dimension..., 2011; Nowakowska, 2013):

1. Nowego podejścia do planowania/programowania strategicznego:

- uwzględnienia terytorialnego wymiaru $\mathrm{w}$ analizach strategicznych (mocniejsze eksponowanie kapitałów terytorialnych, zróżnicowanych czynników i uwarunkowań rozwoju w analizach diagnostycznych);

- większej koncentracji na kluczowych obszarach oddziaływania (koncentracja na tematycznych i terytorialnych priorytetach (tzw. obszary strategicznej interwencji), odejście od rozproszonych interwencji na rzecz zintegrowanych projektów zaadresowanych do konkretnego terytorium);

- wzmacniania planowania dla obszarów funkcjonalnych (mocniejsze uwzględnienie terytorialnego wymiaru w planach i programach strategicznych);

- przebudowy systemu planowania na wszystkich poziomach zarządzania w kierunku ścisłego powiązania wymiaru społeczno-gospodarczego z przestrzennym;

- wzmocnienie debaty środowiskowej i włączenie szerokiego grona interesariuszy w proces programowania rozwoju.

2. Silniejszej koordynacji polityk i uwzględnianie terytorialnego wymiaru:

- przebudowę systemu finansowania polityki rozwoju - przejścia od polityki realizowanej poprzez redystrybucję środków do polityki ukierunkowanej na 
rozwój terytoriów wraz z nowymi instrumentami finansowymi (kontrakty terytorialne, zintegrowane inwestycje terytorialne);

- mocniejsze uwzględnienie wymiaru terytorialnego w analizach efektywności i skuteczności polityki (np. w wielowymiarowych ewaluacjach polityki itp.);

- promowanie eksperymentowania i innowacyjnych sposobów kształtowania rozwoju (fundusze dla innowacyjnych działań terytorialnych; odejście od „kalkowania", powielania działań podejmowanych w ramach polityki rozwoju);

- orientacja na wyniki - poprawa efektywności, upowszechnienie stosowania zestawu wskaźników do oceny efektów polityki, większe wykorzystanie metod ewaluacyjnych;

- tworzenie kompleksowych, wielosektorowych projektów, tzw. projektów zintegrowanych.

3. Zmian instytucjonalnych prowadzących do pogłębienia zasobów wiedzy i debaty strategicznej:

- powołanie nowych instytucji w systemie kształtowania polityki rozwo$\mathrm{ju}$ - krajowego i regionalnego forum i obserwatorium terytorialnego;

- wzmacnianie partnerstwa instytucjonalnego - przeformułowanie roli różnych instytucji publicznych (i relacji pomiędzy nimi) w zakresie programowania i wdrażania polityki rozwoju;

- wprowadzenie nowych mechanizmów koordynacyjnych pomiędzy politykami horyzontalnymi oraz pomiędzy różnymi szczeblami zarządzania, wzmocnienie wielopoziomowego systemu zarządzania (multi-level governance).

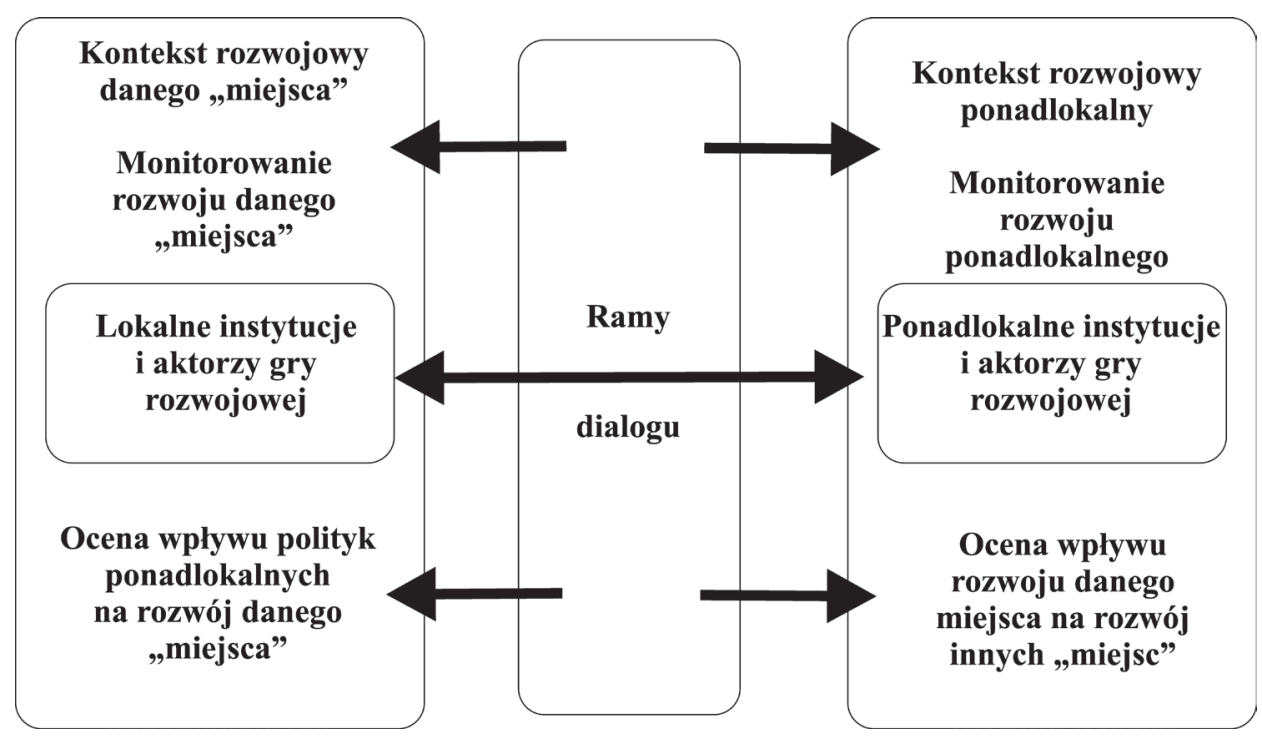

Rysunek 2. Najważniejsze elementy podejścia ukierunkowanego terytorialnie 
Zaproponowana na poziomie UE reorientacja polityki rozwoju pokazuje ogólną filozofię i ramy terytorialno-funkcjonalnego podejścia. Nie wskazano uniwersalnego modelu polityki, precyzyjnie określającego sposób implementacji. Zarysowano jedynie ramy tej koncepcji, pozostawiając poszczególnym krajom możliwości samodzielnego ich dookreślania. Nie istnieje więc jeden model podejścia ukierunkowanego terytorialnie. Każdy z poszczególnych krajów, w zależności od wielkości i struktury administracyjnej, skali problemów czy lokalnych uwarunkowań rozwoju, ma możliwość niezależnego stosowania tego paradygmatu polityki rozwoju.

Reasumując, w praktyce terytorializacja polityk publicznych polega na zróżnicowaniu lokalnym i regionalnym instrumentów polityki, poprzez dostosowanie rozwiązań prawnych, instytucjonalnych, organizacyjnych oraz stopnia, kierunków i sposobu finansowania przedsięwzięć prorozwojowych, do specyficznych potrzeb jednostek terytorialnych. Podejście terytorialne ogniskuje swoją uwagę na trzech fundamentalnych elementach: po pierwsze na terytorialnych zasobach i uwarunkowaniach rozwoju (specyficznych i endogenicznych zasobach, wewnętrznych powiązaniach gospodarczych, więziach w lokalnych społecznościach). Po drugie, na integracji działań podejmowanych w różnych układach instytucjonalnych i wzmacnianie partnerstwa na rzecz budowania rozwoju społeczno-gospodarczego. Po trzecie, na dynamizacji mechanizmów rozwoju w obszarach funkcjonalnych, tworzących spójne terytoria, niezależnie od układu administracyjno-politycznego. Stąd też terytorialny paradygmat rozwoju określany jest często terytorialno-funkcjonalnym lub też zintegrowanym podejściem do kształtowania rozwoju.

\subsection{Nowe instrumenty zintegrowanej polityki w KSRR}

\subsubsection{Kontrakt terytorialny jako instrument poprawy efektywności polityki rozwoju}

Wprowadzanie w życie nowego paradygmatu polityki rozwoju wymaga zastosowania silnych impulsów i motywatorów, wśród których największą skutecznością charakteryzują się instrumenty finansowe, bezpośrednio oddziaływujące na podmioty tworzące lokalną i regionalną politykę. W ramach Krajowej Strategii Rozwoju Regionalnego 2010-2020: Regiony, Miasta, Obszary wiejskie (KSRR ..., 2010) wprowadzono nowe narzędzia służące poprawie efektywności działań związanych z zarządzaniem rozwojem na poziomie krajowym, regionalnym i lokalnym. Są to: kontrakt terytorialny, zintegrowane inwestycje terytorialne, krajowe i regionalne fora terytorialne oraz krajowe i regionalne obserwatoria terytorialne.

Podstawowym instrumentem desygnowanym do poprawy koordynacji i integracji działań w wymiarze przestrzennym i społeczno-gospodarczym oraz 
wzmocnienia partnerstwa pomiędzy rządem i samorządem wojewódzkim jest kontrakt terytorialny. Jest on wynikiem dwustronnych negocjacji pomiędzy ministrem właściwym do spraw rozwoju regionalnego a samorządem województwa odpowiedzialnym za przebieg procesów rozwoju na poziomie regionalnym. Kontrakt terytorialny to instrument planistyczny, zapewniający koordynację i realizację działań prorozwojowych podejmowanych przez rząd i samorząd, ukierunkowanych na osiąganie wspólnych celów, wyznaczonych dla konkretnego terytorium. Instrument ten ma zapewnić większe dostosowanie interwencji sektorowej do potrzeb regionalnych poprzez zderzenie priorytetów krajowych z oczekiwaniami i uwarunkowaniami regionalnymi.

Kontrakt terytorialny określa cele i zadania poszczególnych jego sygnatariuszy oraz wskazuje instrumenty i sposób realizowania interwencji. Identyfikuje obszary strategicznej interwencji, tj. konkretne przedsięwzięcia priorytetowe realizowane na określonym geograficznie obszarze, które wynikają z celów strategicznych rozwoju kraju oraz celów i priorytetów określanych na poziomie regionalnym. Jest on swoistym porozumieniem strony rządowej i samorządowej w zakresie realizacji wspólnych celów rozwojowych. Zawarte w kontrakcie ustalenia dotyczą m.in.:

- celów rozwojowych i głównych kierunków działań wraz ze wskazaniem sposobów ich osiągania przy udziale różnych podmiotów publicznych;

- obszarów koncentracji tematycznej i geograficznej wraz z określeniem priorytetowych inwestycji, których realizacja objęta będzie kontraktem;

- podziału środków na poszczególne obszary tematyczne w ujęciu tematycznym i terytorialnym;

- wkładu krajowego i regionalnego w realizacji przedsięwzięć rozwojowych objętych kontraktem;

- źródeł współfinansowania inwestycji ze środków unijnych i krajowych (tj. rządowych, samorządowych oraz prywatnych);

- przyjętych wskaźników osiągania rezultatów dla wskazanych celów rozwojowych (tematycznych i terytorialnych) (MIR, 2012).

Kontrakty pozwalają na koordynację działań rozwojowych ukierunkowanych terytorialnie, finansowanych w ramach funduszy i programów rządowych, zapewniając integrację i koncentrację dostępnych źródeł krajowych na wspieranie strategicznych celów rozwojowych, w odniesieniu do określonej przestrzeni. Wykorzystane są one także do uzgadniania interwencji w ramach programów operacyjnych na poziomie krajowym i regionalnym do potrzeb realizacji krajowych i regionalnych celów rozwojowych w wybranych obszarach strategicznej interwencji. Pozwala to na lepszą koordynację zaprogramowanych działań publicznych finansowanych ze środków UE.

Reasumując, kontrakt terytorialny jest nowym finansowym instrumentem polityki regionalnej, definiowanym jako: (1) instrument zwiększania koordynacji i skuteczności polityk publicznych realizowanych na różnych szczeblach zarządzania; (2) mechanizm uterytorialnienia polityki rozwoju poprzez zapewnianie 
tematycznej i geograficznej koncentracji interwencji publicznej oraz (3) narzędzie poprawy efektywności alokacji środków finansowych wydawanych w ramach polityki spójności 2014-2020.

\subsubsection{Zintegrowane inwestycje terytorialne jako instrument terytorialnej koncentracji środków publicznych}

W ramach kontraktu terytorialnego wyodrębniono nowy instrument dedykowany obszarom miejskim lub innym obszarom funkcjonalnym - Zintegrowane Inwestycje Terytorialne (ZIT). Celem realizacji zintegrowanych inwestycji terytorialnych jest wspieranie zrównoważonego i zintegrowanego rozwoju obszarów miejskich, głównie miast wojewódzkich i ich obszarów funkcjonalnych. W szczególności chodzi o zwiększanie udziału miast $\mathrm{i}$ ich obszarów funkcjonalnych w tworzeniu rozwoju oraz wzmacnianie współpracy i integracji działań na obszarach funkcjonalnych miast, w których komplementarność działań i partnerstwo różnych jednostek publicznych jest kluczowym czynnikiem dynamizacji procesów rozwoju (MIR, 2013).

Realizacja ZIT na obszarach funkcjonalnych wymaga stworzenia partnerstwa reprezentującego dany obszar. Warunki konieczne to między innymi przygotowanie strategii rozwoju obszaru funkcjonalnego, zawiązanie zinstytucjonalizowanej formy partnerstwa czy podpisanie porozumienia dla realizacji ZIT w województwie z Instytucją Zarządzającą Regionalnym Programem Operacyjnym. W skład związku ZIT mogą wejść zarówno samorządy gminne, powiaty, jak i samorząd wojewódzki - w zależności od zakresu jego działania. Zadania, jakie będzie pełnił związek ZIT, jak też jego forma prawna uzależnione są od zakresu i charakteru realizowanych zadań.

Zintegrowane Inwestycje Terytorialne to nowy instrument finansowy „zreformowanej" polityki rozwoju określonej na lata 2014-2020. Narzędzie, zaproponowane przez Komisję Europejską, zakłada delegację części zadań związanych z wdrażaniem programów operacyjnych (np. wybór projektów, przygotowanie kryteriów wyboru projektów, etc.) na poziom niższy niż regionalny (subregionalny).

\subsubsection{Regionalne forum terytorialne jako instrument wzmacniania debaty publicznej o rozwoju terytorium}

Skuteczne i efektywne prowadzenie polityki regionalnej wymaga wzmocnienia warunków instytucjonalnych dla strategicznego myślenia o rozwoju zarówno na poziomie krajowym, regionalnym, jak i subregionalnym. Odpowiedzią na ten 
postulat jest utworzenie Krajowego Forum Terytorialnego (KFT) oraz powstawanie regionalnych forów terytorialnych (RFT). Zarówno KFT i RFT stanowią platformę wymiany wiedzy, doświadczeń i informacji stymulującą strategiczne myślenie o rozwoju (MRR, 2011). Główne cele działania forum terytorialnego to:

- ocena postępów realizacji polityki regionalnej oraz skutków przestrzennych realizacji polityk sektorowych;

- formułowanie opinii i rekomendacji w zakresie wymiaru terytorialnego polityk krajowych i UE w oparciu o dostępne badania, ewaluacje i raporty, w tym analizy dokonywane przez obserwatoria służące monitorowaniu polityki regionalnej;

- inicjowanie debaty na temat kierunków i form realizacji polityki regionalnej;

- formułowanie rekomendacji dotyczących zmian legislacyjnych w zakresie polityki regionalnej;

- rekomendowanie działań wobec rożnych instytucji publicznych, samorządów terytorialnych i innych podmiotów, w szczególności w obszarze polityki przestrzennej, regionalnej, miejskiej, transportowej czy rozwoju wsi;

- opiniowanie raportów, planów rozwoju i innych dokumentów strategicznych służące wymianie wiedzy, doświadczeń i informacji między różnymi podmiotami publicznymi i niepublicznymi aktywnie zaangażowanymi na rzecz kształtowania rozwoju terytorium.

\subsubsection{Regionalne obserwatoria terytorialne jako instrument budowania systemu monitoringu terytorialnego}

Powołanie nowych instytucji do realizacji polityki regionalnej w postaci obserwatoriów rozwoju terytorialnego: Krajowego Obserwatorium Terytorialnego (KOT) oraz regionalnych obserwatoriów terytorialnych (ROT) tworzy nowy system współpracy i przepływu informacji między najważniejszymi podmiotami publicznymi biorącymi udział w tworzeniu i realizacji polityki rozwoju. Głównym celem ich działania jest wzrost zainteresowania strategicznym myśleniem o rozwoju na poziomie krajowym, regionalnym i subregionalnym oraz poprawa jakości kształtowania polityk publicznych ukierunkowanych terytorialnie, między innymi poprzez (MRR, 2012):

- stworzenie transparentnego i elastycznego systemu pozyskiwania i agregowania danych oraz wypracowanie standardów ich wymiany pomiędzy podmiotami władzy i administracji publicznej;

- analizę kluczowych procesów i zjawisk mających wpływ na politykę regionalną, ze szczególnym uwzględnieniem oddziaływania polityk i strategii wspólnotowych UE na politykę regionalną; 
- poprawę jakości planowania strategicznego dzięki dostarczaniu porównywalnych i agregowalnych danych dotyczących trendów rozwojowych i prognozowania zmian społeczno-gospodarczych w układach terytorialnych;

- upowszechnienie wiedzy na temat rozwoju regionalnego poprzez zbudowanie systemu stwarzającego warunki do szybkiego i sprawnego przepływu informacji pomiędzy podmiotami odpowiedzialnymi za prowadzenie polityki rozwoju;

- poprawę monitorowania i oceny całości interwencji publicznej mającej wpływ terytorialny.

\section{Zintegrowane planowanie rozwoju}

\subsection{Istota zintegrowanego podejścia do planowania rozwoju jednostki terytorialnej}

Skala i szybkość zmian zachodzących w systemach społecznych, gospodarczych i przestrzennych w zglobalizowanej gospodarce jest tak duża, że konieczna staje się zasadnicza zmiana systemu planowania. Odpowiedzią na ten postulat jest planowanie zintegrowane (lansowane w ramach idei place based policy), które postrzegane jest jako model bardziej adekwatny do dynamicznych i zmiennych w czasie i przestrzeni terytoriów (obszarów funkcjonalnych). Nie chodzi tylko o holistyczne i zintegrowane myślenie w planowaniu sektorowym czy planowaniu przestrzennym, ale stworzenie nowego, zintegrowanego systemu planowania i planów adekwatnych do współczesnych cech gospodarki. Konieczne jest wprowadzenie do polityki rozwoju jednostek terytorialnych różnych szczebli planów zintegrowanych, a nie tylko lansowanie procedur planowania zintegrowanego $\mathrm{w}$ istniejącym dualnym i sektorowym systemie planowania rozwoju (Markowski, 2013).

Planowanie zintegrowane wyrosło z krytyki dotychczasowych metod i procedur planowania, tworzących dychotomiczny system w podziale na planowanie przestrzenne i planowanie społeczno-gospodarcze. Nowy paradygmat jest próbą holistycznego podejścia do analizy i kształtowania procesów rozwoju terytorialnego. Jest planowaniem „całościowym”, łączącym różne wymiary i konteksty procesów rozwoju. Uwzględnia silne i złożone współzależności, i powiązania zachodzące w procesach rozwoju oraz bazuje na kompleksowych rachunkach korzyści i kosztów (Markowski, 2013). Opiera się na podejściu terytorialno-funkcjonalnym i radykalnie zrywa z sektorowym podejściem do kształtowania procesów rozwoju. Eksponuje wzajemne zrównoważone powiązania między podsystemem gospodarczym, społecznym i środowiskiem. Wskazuje na konieczność uwzględnienia w procedurach analitycznych i planistycznych oddziaływania wielu elementów związanych z funkcjonowaniem różnych sfer aktywności ludzkiej. 
Nowe podejście do planowania rozwoju wprowadza istotne zmiany w formy, treści i metody planowania, a także w struktury organizacyjne organów władzy publicznej i system wdrażania polityki rozwoju. Integracja planowania powinna nastąpić zarówno w układzie horyzontalnym, międzysektorowym, jak i między poziomami władzy. Jest to planowanie o charakterze sieciowym, bazujące na partycypacji wszystkich aktorów funkcjonujących w terytorium.

Główne, charakterystyczne cechy planowania zintegrowanego to:

- planowanie dla jednorodnych, wewnętrznie powiązanych terytoriów-obszarów funkcjonalnych (nie dla jednostek administracyjnych);

- mocne wykorzystanie endogeniczności i specyficzności zasobów i mechanizmów rozwoju; eksponowanie różnorodności zasobów i procesów w analizach strategicznych;

- akcentowanie współzależności i powiązań pomiędzy elementami (społecznymi, gospodarczymi i przestrzennymi) tworzącymi terytorium (ujęcie funkcjonalne);

- zróżnicowanie terytorialne polityki strategicznej - integracja celów, działań i instrumentów oddziaływania dla poszczególnych terytoriów (koncentracja tematyczna i terytorialna polityki rozwoju - identyfikacja obszarów strategicznej interwencji);

- akcentowanie adekwatności działań do istniejącego poziomu i problemów rozwoju poszczególnych terytoriów (odejście od uniwersalności interwencji publicznych na rzecz zindywidualizowanego podejścia do rozwoju);

- integracja planowania społeczno-gospodarczego z planowaniem przestrzennym;

- integracja procesów wdrażania planów rozwoju - wielopoziomowe, wielopodmiotowe, wielo(między)sektorowe podejście w zarządzaniu rozwojem (Nowakowska, 2013).

W nowym paradygmacie należy rozróżnić pojęcie zintegrowanego planu od zintegrowanego planowania (rys. 3). Powstaje zatem zasadnicze pytanie, czy samo zintegrowanie planowania pod względem proceduralnym będzie rozwiązaniem wystarczającym dla wprowadzenia nowego paradygmatu planowania. Czy konieczne jest stworzenie nowego systemu zintegrowanych planów? W pierwszym przypadku, w ramach istniejącego systemu planowania rozwoju, zintegrowane podejście jest wprowadzane poprzez ewolucyjne zmiany w zakresie formy, treści i zakresu planowania. Wprowadzone zostaje holistyczne i zintegrowane myślenie w istniejący model planowania rozwoju jednostek terytorialnych (w planowaniu wyspecjalizowanym i przestrzennym). W drugim przypadku następuje zasadnicza zmiana systemu planowania polegająca na stworzeniu nowego zintegrowanego systemu planowania i planów adekwatnych do współczesnych cech gospodarki. Następuje tu systemowe wprowadzenie do polityki rozwoju planów zintegrowanych (a nie tylko lansowanie procedur planowania zintegrowanego jak w pierwszym przypadku). Zintegrowany plan to dokument ujmujący w zapisach ustalenia wielu współzależnych sfer. 

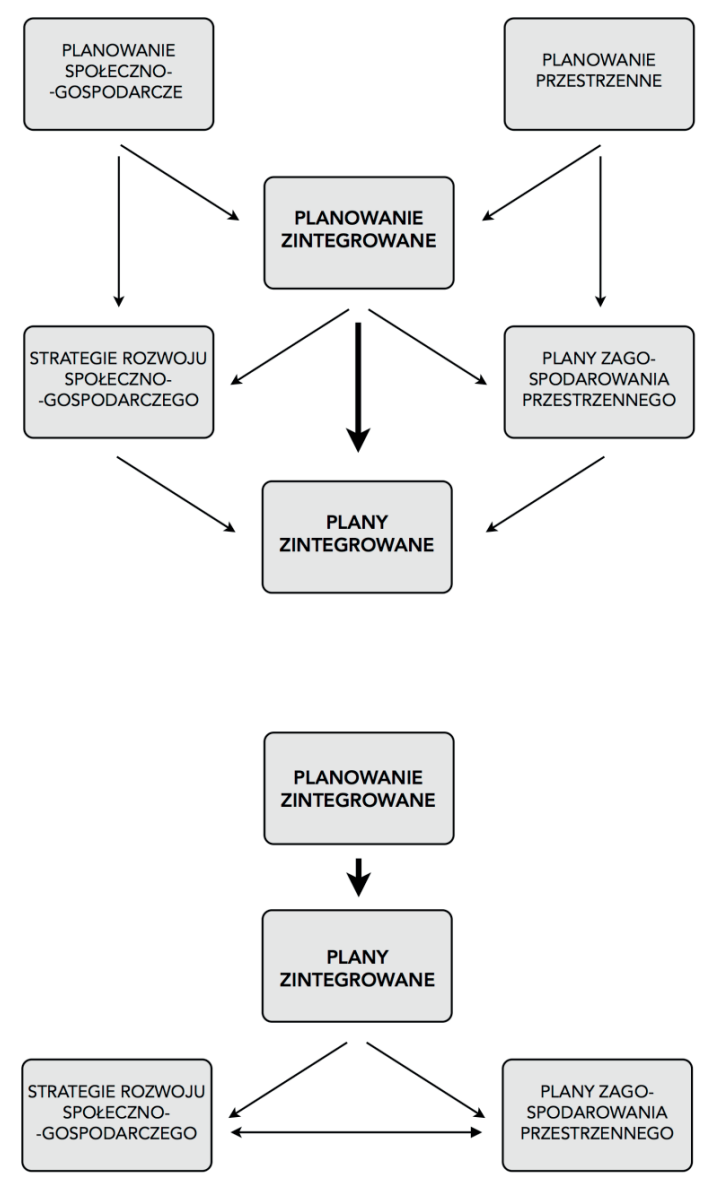

Rysunek 3. Istniejący i postulowany model planowania zintegrowanego

Źródło: Markowski, 2013

Jak wskazuje T. Markowski, w praktyce legislacyjnej integralność planowania można bardzo łatwo upozorować. W tym celu stosuje się pewne zapisy $\mathrm{w}$ aktach prawnych mówiących, iż $\mathrm{w}$ procedurze planowania uwzględnia się te lub inne dokumenty i ustalenia. W rzeczywistości mamy do czynienia jedynie z postulowanym planowaniem zintegrowanym, które w rezultacie nie daje planu zintegrowanego, a jedynie zmniejsza kolizyjność między istniejącymi planami i politykami (Markowski, 2013).

Planowanie zintegrowane łączy w sobie trojakie spojrzenie na terytorium. Po pierwsze jest to dogłębne spojrzenie do wewnątrz terytorium w celu identyfikacji kapitałów terytorialnych, sieci powiązań i współzależności zachodzących pomiędzy sferą społeczną, gospodarczą i przestrzenną w rozwoju. Po drugie, jest to 
szerokie spojrzenie na zewnątrz terytorium, na otoczenie, w którym funkcjonuje układ terytorialny poprzez określenie siły i charakteru (pozytywnego lub negatywnego) interakcji zachodzących pomiędzy terytorium a otoczeniem. Wreszcie po trzecie, jest to spojrzenie w przyszłość czyli określenie pożądanych zmian i strategicznych interwencji, selektywnie wybranych dla konkretnego terytorium.

Koncepcja zintegrowanego planowania mocno osadzona jest w paradygmacie rozwoju zrównoważonego. $Z$ tej perspektywy zintegrowane plany rozwoju to system wzajemnych, powiązanych działań, mających na celu trwałe usprawnienia gospodarczych, fizycznych, społecznych i środowiskowych warunków rozwoju (Tolle, 2014). Silne odniesienie do planowania zintegrowanego odnajdujemy także w Karcie Lipskiej, w której podkreślany jest fakt, że narzędzia planowania powinny być koordynowane na poziomie lokalnym i miejskim oraz angażować obywateli i innych partnerów, którzy mogą wnieść znaczny wkład w kształtowanie przyszłej jakości każdego obszaru w wymiarze gospodarczym, społecznym, kulturowym i ekologicznym (Karta Lipska, 2007, s. 3).

\subsection{Obszary funkcjonalne - podstawowa jednostka planowania}

Planowanie zintegrowane terytorialnie jest narzędziem nowoczesnej polityki terytorialnej, która próbuje ograniczyć negatywne skutki sektorowego podejścia do kształtowania polityk rozwoju. Jest ono także odpowiedzią na patologie wynikające z rozbieżności między planowaniem przestrzennym i gospodarczym oraz z niesprawności rynku i rozwiązań regulacyjnych instytucji publicznych. W tym podejściu podstawową jednostką planistyczną nie jest jednostka administracyjna, a obszar funkcjonalny.

Obszar funkcjonalny to fragment przestrzeni geograficznej, której granice określają podmioty prowadzące aktywności w sferze społecznej, gospodarczej lub politycznej. W Koncepcji Zagospodarowania Przestrzennego Kraju obszar funkcjonalny zdefiniowany został jako zwarty układ przestrzenny, składający się z funkcjonalnie powiązanych terenów, charakteryzujących się wspólnymi uwarunkowaniami i przewidywanymi jednolitymi celami rozwoju (KPZK, 2011). Obszary funkcjonalne według MRR to wyodrębnione przestrzennie specyficzne kompleksy terytorialne charakteryzujące się wspólnymi cechami społeczno-gospodarczymi i przestrzennymi (MRR, 2011). Są to obszary charakteryzujące się wspólnym kapitałem terytorialnym, silnymi wewnętrznymi powiązaniami i współzależnościami w mechanizmach rozwoju. To co łączy te obszary to także wspólne problemy i wyzwania rozwoju, a zarazem ich odrębność względem otoczenia.

W praktyce, o delimitacji obszaru funkcjonalnego decyduje zespół funkcji dominujących. Obszary funkcjonalne są dynamiczne w czasie i przestrzeni, dlatego też trudne do jednoznacznej delimitacji. Ich zasięg jest rezultatem zmienno- 
ści funkcji wynikającej między innymi ze zmienności rynków zbytu i zaopatrzenia, zmienności liczby i struktury firm, miejsc pracy, oddziaływania skutków zewnętrznych związanych z prowadzoną działalnością etc. Zasięg obszarów funkcjonalnych wynika także z cech fizycznych środowiska geograficznego, bioróżnorodności czy zaspokojenia potrzeby kontaktu człowieka z przyrodą (Markowski, 2013).

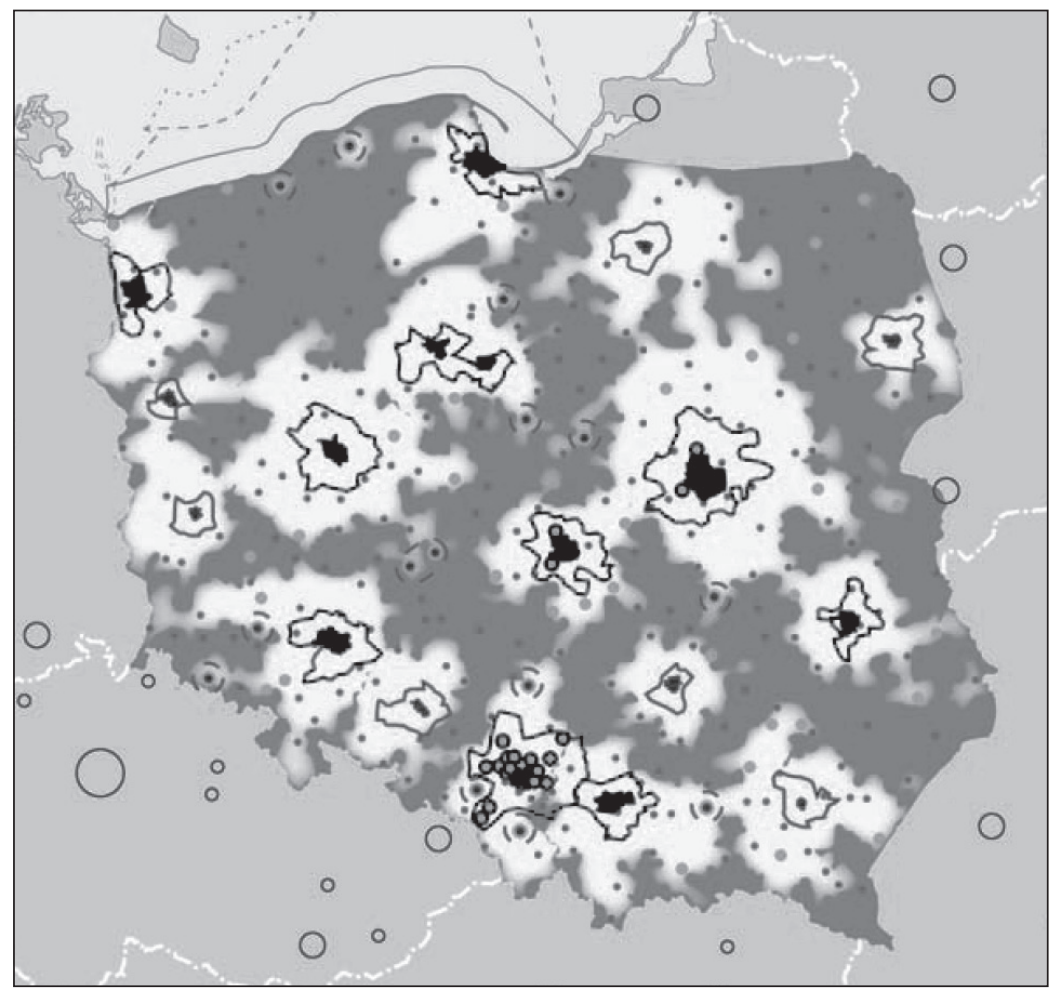

Rysunek 4. Miejskie i wiejskie obszary funkcjonalne w Polsce

Źródło: MRR, 2012

Najczęściej delimitowane obszary funkcjonalne to:

- miejskie obszary funkcjonalne;

- wiejskie obszary funkcjonalne;

- obszary szczególnego zjawiska w skali makroregionalnej;

- obszary kształtowania potencjału rozwojowego;

- obszary funkcjonalne wymagające rozwoju funkcji.

Pojęciem pokrewnym w stosunku do obszaru funkcjonalnego jest pojęcie obszaru strategicznej interwencji. Jest to nowe pojęcie w polityce rozwoju, interpretowane jako obszar, wobec którego wymagana jest interwencja rządu i/lub 
władz samorządowych, ze względu na szczególny charakter i oddziaływanie tego obszaru w procesach rozwoju. Wyróżniamy dwa podstawowe obszary strategicznej interwencji: po pierwsze obszary, w których zidentyfikowano istotny problem, blokujący procesy rozwoju, a samorząd terytorialny nie jest sam w stanie go rozwiązać; po drugie obszary, które ze względu na skumulowany tam potencjał społeczny, gospodarczy lub środowiskowy wywierają lub mogą w przyszłości wywierać istotny wpływ na rozwój kraju/regionu/powiatu (MRR, 2011). W konsekwencji podstawowe kryteria delimitacji obszarów strategicznej interwencji w strategiach rozwoju to:

- wspólne, specyficzne uwarunkowania rozwoju i cechy społeczne, gospodarcze i środowiskowe;

- występowanie wspólnych barier i podobnych problemów rozwojowych (tzw. obszary problemowe);

- możliwość zastosowania wspólnych typów i narzędzi interwencji publicznej, możliwość zastosowania wspólnej polityki rozwoju (Zintegrowane planowanie, 2013).

W nowym podejściu, obszary funkcjonalne stają się zatem podstawową płaszczyzną planowania, wyznaczoną zgodnie z realnym zasięgiem procesów rozwoju, bez uwzględniania administracyjnych granic terytorialnego podziału kraju. Planowanie terytorialne polega na odejściu od planowania sektorowego dla jednostek administracyjnych na rzecz planowania zintegrowanego, łączenia planowania przestrzennego i gospodarczego w jeden, spójny dokument planistyczny opracowywany dla obszarów funkcjonalnych.

\subsection{Logika i specyfika zintegrowanego planu strategicznego}

Zintegrowane planowanie nie jest jednoznacznie zdefiniowane w polskim systemie planistycznym, choć w ostatnich latach stało się pojęciem powszechnie wykorzystywanym. Zintegrowany plan (strategię) rozwoju można definiować z dwóch perspektyw. W ujęciu ekonomicznym jest to koncepcja rozwoju obszaru funkcjonalnego, w ramach której określone zostają powiązania i zasoby terytorialne oraz ich optymalne wykorzystanie na rzecz rozwoju, przy uwzględnieniu warunków zewnętrznych. Jest to kompleksowa, perspektywiczna koncepcja rozwoju jednostki terytorialnej, określająca cele rozwoju i sposoby ich osiągania. Strategia zintegrowana jest holistyczną koncepcją, obejmującą wszystkie płaszczyzny życia terytorium, jest koncepcją o długim horyzoncie czasowym, mającą zapewnić harmonijny i zrównoważony rozwój.

Z perspektywy zarządzania, zintegrowana strategia to nadrzędny instrument zarządzania rozwojem, w ramach którego określone zostają sekwencje działań, zintegrowane projekty i narzędzia. Strategia rozwoju jest „drogowskazem”, punktem odniesienia dla koordynacji bieżących decyzji podejmowanych przez podmioty 
lokalne/regionalne. Jest instrumentem integracji działań i podmiotów, harmonizowania polityki rozwoju, z silnym oddziaływaniem informacyjno-marketingowym.

Planowanie zintegrowane bazuje na podobnej jak w przypadku klasycznej metody planowania strategicznego logice i strukturze planu. Istotne różnice dotyczą natomiast delimitacji obszaru planowania, treści planu ( $\mathrm{tj}$. interpretacji zasobów i procesów rozwoju, identyfikacji strategicznych uwarunkowań) oraz sposobów i narzędzi ich wdrażania. Ogólnie ujmując, proces tworzenia zintegrowanej strategii rozwoju składa się z trzech zasadniczych etapów:

1. Analiza strategiczna - diagnozowanie stanu rozwoju obszaru funkcjonalnego w celu identyfikacji zasobów, problemów i bariery rozwoju, w kontekście zewnętrznych uwarunkowań rozwoju;

2. Zintegrowane planowanie strategiczne - etap kreowania zintegrowanego, holistycznego i długookresowego planu rozwoju, określającego strategiczne cele i zintegrowane projekty;

3. Planowanie operacyjne-etap opracowania planów realizacji projektów zintegrowanych wraz ze stworzeniem systemu ewaluacji i monitorowania terytorialnego.

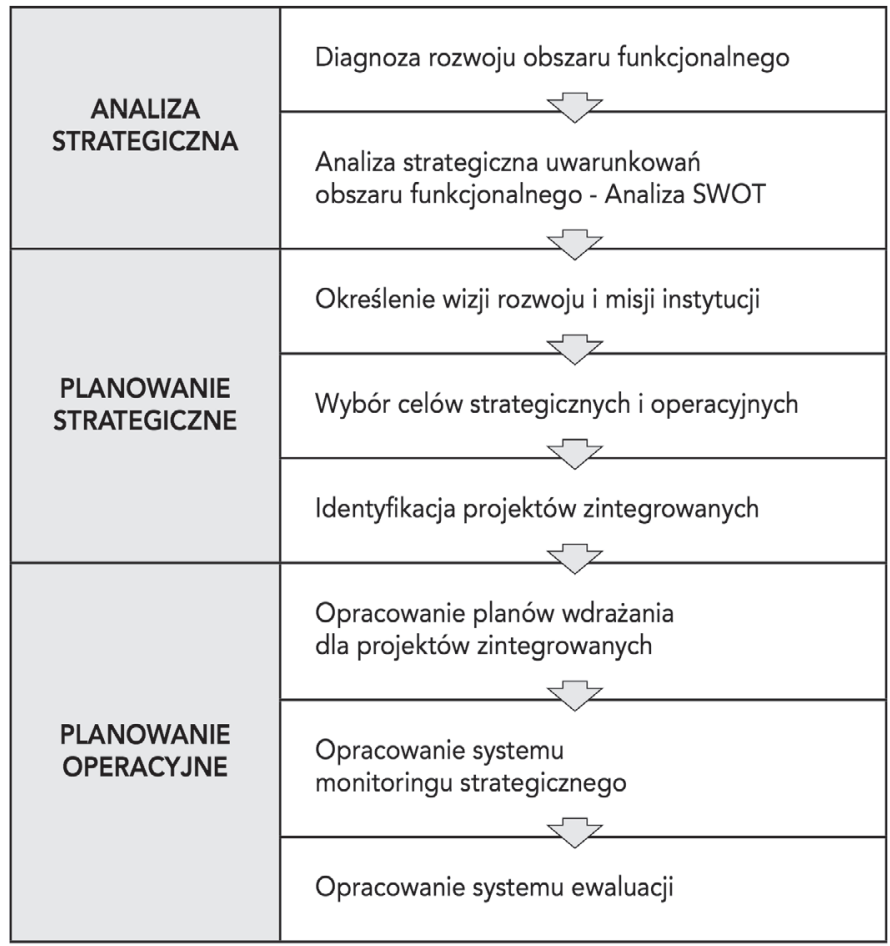

Rysunek 5. Proces budowania zintegrowanych strategii rozwoju 
Warunkiem koniecznym skutecznego zarządzania rozwojem jednostki terytorialnej jest współistnienie planowania strategicznego i operacyjnego. Planowanie strategiczne ma charakter ogólny, koncepcyjny, jest planowaniem długookresowym. Planowanie operacyjne ma wykonawczy charakter, konkretyzuje i przygotowuje wdrażanie zapisów zintegrowanego planu. Zintegrowana strategia jako odzwierciedlenie długookresowego spojrzenia na procesy rozwoju pełni przede wszystkim funkcje koncepcyjną, koordynacyjną i informacyjną. Planowanie operacyjne (programy bieżące), stanowiące fundament realizacji strategii, ma na celu integrowanie działań bieżących z ustaleniami długookresowych planów rozwoju. Jest przełożeniem celów i kierunków rozwoju na konkretne projekty zintegrowane oraz bieżące decyzje i działania. Dominujące funkcje planów o charakterze operacyjnym to funkcja koordynacyjna, kontrolna i regulacyjna.

\subsubsection{Analiza strategiczna - diagnozowanie zasobów, procesów i uwarunkowań rozwoju obszaru funkcjonalnego}

Proces budowania zintegrowanej strategii rozwoju rozpoczyna analiza strategiczna składająca się z dwóch etapów: (1) diagnozy stanu rozwoju obszaru funkcjonalnego, (2) analizy strategicznych uwarunkowań rozwoju (SWOT). Diagnoza to holistyczna analiza, pozwalająca na wydobycie specyfiki danej jednostki, tempa zachodzących przemian, czynników pozytywnych i negatywnych determinujących jej rozwój. Prawidłowa diagnoza powinna określać aktualny stan rozwoju, wskazywać kluczowe problemy i wyjaśniać przyczyny, które doprowadziły do obecnej sytuacji. Stanowi ona punkt wyjścia i podstawę do formułowania strategicznych uwarunkowań oraz identyfikowania wyzwań rozwoju. W szczególności, część diagnostyczna procesu zintegrowanego planowania polega na:

- ocenie stanu rozwoju jednostki terytorialnej poprzez analizę zasobów i problemów rozwoju, wskazanie czynników i barier rozwoju jednostki terytorialnej;

- identyfikacji specyficzności i endogeniczności zasobów i mechanizmów rozwoju;

- rozpoznaniu procesów i trendów w rozwoju jednostki terytorialnej;

- identyfikowaniu powiązań i współzależności w mechanizmach rozwoju jednostki terytorialnej;

- określeniu przyczyn i skutków stanu istniejącego w rozwoju jednostki terytorialnej.

Drugim etapem analizy strategicznej dla obszaru funkcjonalnego jest określenie strategicznych (zewnętrznych i wewnętrznych) uwarunkowań rozwoju. Najczęściej stosowaną tu metodą jest analiza SWOT - analiza sił i słabości, szans i zagrożeń w rozwoju jednostki terytorialnej. SWOT to strategiczna analiza pozy- 
tywnych i negatywnych uwarunkowań rozwoju jednostki terytorialnej. Siły i słabości to zjawiska tkwiące w jednostce terytorialnej (perspektywa wewnętrzna), które mamy możliwość kształtować (bezpośrednio na nie oddziaływać). Szanse i zagrożenia to zjawiska o charakterze zewnętrznym, występujące w bliskim i dalszym otoczeniu, działania jednostki terytorialnej, na które nie mamy lub mamy bardzo ograniczone możliwości oddziaływania. Są to zasoby i procesy wynikające z otoczenia (np. w sąsiedniej jednostce terytorialnej, regionie, Unii Europejskiej). Szanse to zjawiska mogące stanowić istotny impuls rozwojowy, zaś zagrożenia to zjawiska osłabiające lub ograniczające możliwości rozwojowe jednostki terytorialnej (Dziemianowicz, Szmigiel-Rawska, Nowicka, Dąbrowska, 2012; Chądzyński, Nowakowska, Przygodzki, 2008). Przygotowywanie analizy SWOT ma na celu optymalne wykorzystanie zasobów jednostki terytorialnej oraz redukowanie zagrożeń i dyskontowanie szans, jakie znajdują się w otoczeniu.

Tabela 1. Kategorie analizy SWOT

\begin{tabular}{|l|l|l|l|l|}
\hline & \multicolumn{1}{|c|}{$\begin{array}{c}\text { Siły (atuty) } \\
(\text { Strenghts })\end{array}$} & $\begin{array}{c}\text { Słabości } \\
\text { (Weeknesses })\end{array}$ & $\begin{array}{c}\text { Szanse } \\
\text { (Opportunities })\end{array}$ & \multicolumn{1}{|c|}{$\begin{array}{c}\text { Zagrożenia } \\
\text { (Threats })\end{array}$} \\
\hline $\begin{array}{l}\text { Charakter } \\
\text { oddziaływania }\end{array}$ & Pozytywny & Negatywny & Pozytywny & Negatywny \\
\hline $\begin{array}{l}\text { Lokalizacja } \\
\text { zjawiska }\end{array}$ & $\begin{array}{l}\text { Jednostka teryto- } \\
\text { rialna }\end{array}$ & $\begin{array}{l}\text { Jednostka teryto- } \\
\text { rialna }\end{array}$ & $\begin{array}{l}\text { Otoczenie jed- } \\
\text { nostki teryto- } \\
\text { rialnej }\end{array}$ & $\begin{array}{l}\text { Otoczenie jed- } \\
\text { nostki teryto- } \\
\text { rialnej }\end{array}$ \\
\hline $\begin{array}{l}\text { Możliwość } \\
\text { oddziaływania/ } \\
\text { kształtowania } \\
\text { zjawiska }\end{array}$ & Silna & Silna & Słaba lub brak & Słaba lub brak \\
\hline
\end{tabular}

Źródło: opracowanie własne.

W zintegrowanym podejściu do planowania rozwoju lansowana jest pogłębiona analiza SWOT, wprowadzająca dodatkowy wymiar uwarunkowań - wewnętrzne szanse i zagrożenia. W ten sposób uwzględnione zostają silne współzależności wewnętrzne, zachodzące pomiędzy sferą społeczną, gospodarczą i środowiskową, które przyjmują charakter wewnętrznych szans lub wewnętrznych zagrożeń dla rozwoju, wzmacniając lub osłabiając procesy rozwoju w analizowanej sferze. Istotą tej analizy jest potrójna heliksa współzależności, w której tzw. wewnętrzne uwarunkowania (tj. dla systemu społecznego będzie to oddziaływanie ze strony gospodarki i środowiska) zmieniają się w wewnętrzne szanse i zagrożenia. Analiza SWOT jest swojego rodzaju łącznikiem i pomostem pomiędzy diagnozą a częścią projekcyjną planowania zintegrowanego. Stanowi ona ocenę zjawisk opisywanych w diagnozie i podstawę do dokonywania wyborów o charakterze strategicznym. 


\subsubsection{Strategiczne planowanie}

Planowanie strategiczne (długookresowe) ma charakter koncepcyjny, jest podejściem holistycznym - całościowym spojrzeniem na procesy i problemy rozwoju terytorium. Określa ono wizję rozwoju, misję oraz cele strategiczne. Planowanie strategiczne rozwoju jednostki terytorialnej rozpoczyna formułowanie wizji rozwoju jednostki terytorialnej. Jest to pożądany i oczekiwany w przyszłości stan jej rozwoju, obraz, który chcemy osiągnąć. Wizja określa rangę i atrakcyjność danej jednostki, profil gospodarczy, jakość życia mieszkańców, odzwierciedla aspiracje lokalne. Wskazuje kluczowe idee, wokół których następować powinna integracja lokalna i budowanie tożsamości terytorialnej. Jest wyobrażeniem przyszłości jednostki terytorialnej (Chądzyński, Nowakowska, Przygodzki, 2008).

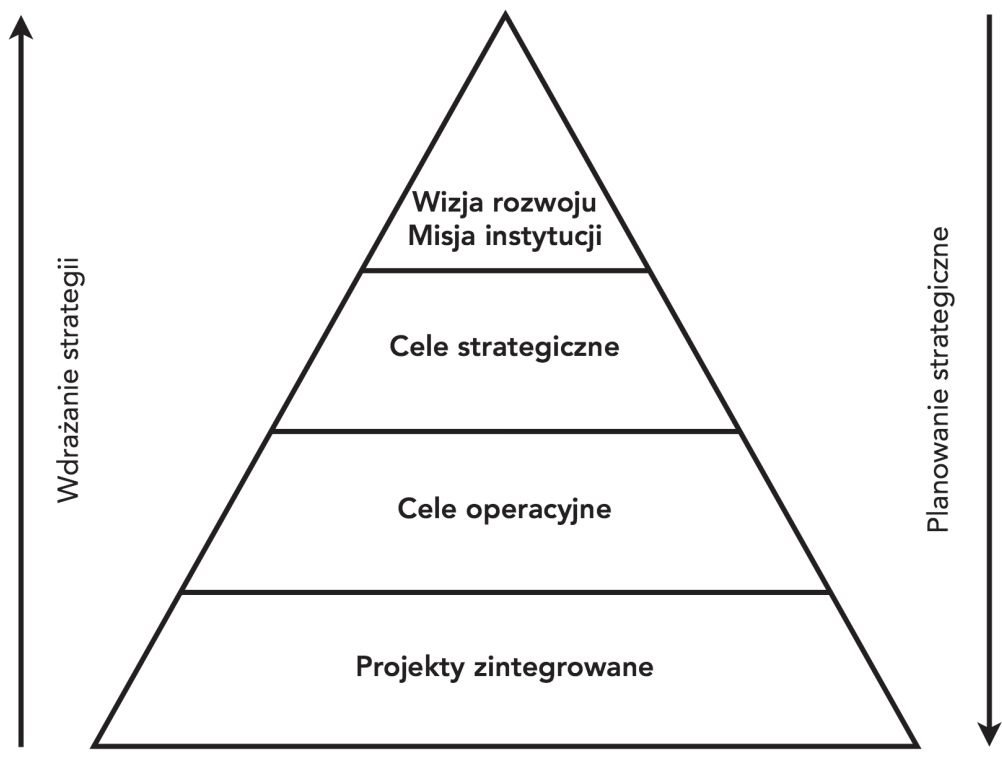

Rysunek 6. Piramida planowania strategicznego (od ogółu do szczegółu)

Źródło: opracowanie własne

Równolegle określona zostaje misja instytucji/organizacji (w przypadku obszaru funkcjonalnego może to być formalna lub nieformalna grupa, związek gmin utworzony dla wdrażania zintegrowanego planu). Misja to specyficzny cel działania organizacji odróżniający ją od innych instytucji tego samego rodzaju. Misja określa fundamentalne i specyficzne kierunki działania, wskazuje na to, 
co organizacja próbuje osiągnąć poprzez swoje działanie (Chądzyński, Nowakowska, Przygodzki, 2008). W przypadku jednostek samorządu terytorialnego cel ich działania, zadania i kompetencje w sposób ogólny (uniwersalny) określają ustawy i inne akty prawne normujące ich funkcjonowanie. Misja ma na celu doprecyzowanie, uszczegółowienie celów działania struktur samorządu terytorialnego, zaangażowanych w proces kształtowania rozwoju obszaru funkcjonalnego.

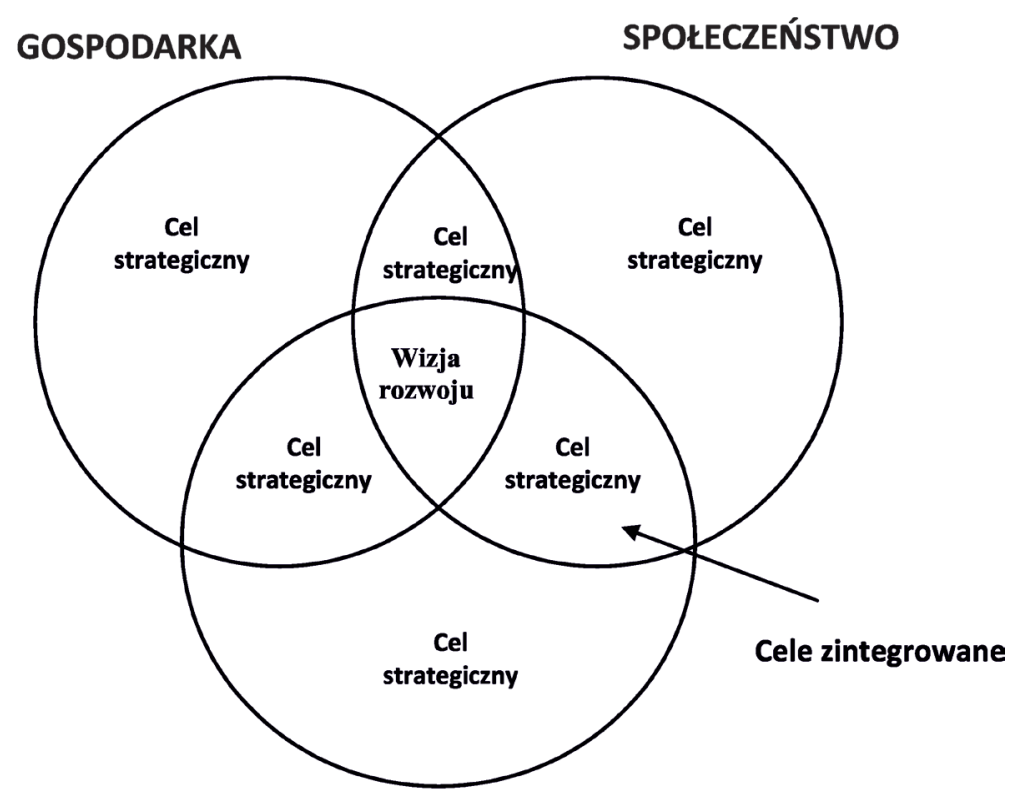

PRZESTRZEŃ

Rysunek 7. Rozeta celów strategicznych w planowaniu zintegrowanym

Źródło: opracowanie własne

Kolejnym krokiem jest dekompozycja wizji na strategiczne cele rozwoju jednostki terytorialnej. Określenie celów rozwoju stanowi najważniejszy punkt opracowywania strategii. Wybór strategicznych celów rozwoju jednostki terytorialnej powinien być uzależniony przede wszystkim od: uwarunkowań wewnętrznych oraz zewnętrznych, prognozowanych trendów rozwoju oraz aspiracji lokalnej społeczności. W budowaniu strategii rozwoju równie ważnym jak wybór celów strategicznych jest określenie taktyki ich osiągnięcia. Następuje to poprzez wskazanie celów operacyjnych oraz projektów zintegrowanych, których realizacja powinna przynieść osiągnięcie spodziewanych efektów. 


\subsubsection{Planowanie operacyjne - określenie planów realizacji projektów zintegrowanych}

W istniejącej formule prawno-administracyjnej sens opracowania zintegrowanej strategii rozwoju istnieje jedynie w sytuacji, gdy we władzach samorządowych $\mathrm{i}$ innych podmiotach istnieje rzeczywista potrzeba posiadania takiego planu poparta chęciami jego realizacji. Aby zintegrowana strategia rozwoju stała się rzeczywistym instrumentem zarządzania rozwojem (a nie jedynie „martwym” dokumentem planistycznym) musi być skutecznie wdrażana i realizowana. Wymaga to przygotowania planów realizacji poszczególnych projektów zintegrowanych. Dla każdego projektu powinien zostać opracowany plan operacyjny określający między innymi:

- cel i istotę wdrażania projektu zintegrowanego;

- podmiot odpowiedzialny za realizację projektu oraz podmioty współrealizujące;

- zasoby finansowe wraz z określeniem źródeł finansowania projektu zintegrowanego;

- harmonogram i etapy realizacji projektu zintegrowanego;

- spodziewane efekty realizacji projektu w wymiarze gospodarczym, społecznym i przestrzennym;

- system informowania o przebiegu prac nad wdrażaniem projektu zintegrowanego (monitoring);

- system analizowania postępów we wdrażaniu projektów zintegrowanych (ewaluacja).

Opracowanie zintegrowanego planu nie jest jednorazowym działaniem. Strategiczny plan winien być weryfikowany i aktualizowany co pewien okres, stosownie do zachodzących zmian w zewnętrznych i wewnętrznych warunkach działania jednostki terytorialnej. Konieczne jest zatem stworzenie systemu monitoringu i ewaluacji zintegrowanej strategii rozwoju. Stworzenie systemu monitoringu umożliwi z jednej strony analizę procesów społeczno-gospodarczych o charakterze strategicznym, z drugiej zaś kontrolowanie realizacji strategii.

Monitoring jest procesem systematycznego zbierania i analizowania informacji ilościowych i jakościowych dotyczących postępów w realizacji zintegrowanego planu. Jest to proces ciągłego obserwowania i śledzenia zmian zachodzących we wdrażaniu strategii i projektów zintegrowanych. Monitoring bazuje na systemie wskaźników, które opracowywane powinny być dla każdego celu strategicznego i projektu zintegrowanego. Proces ten określany jest mianem kwantyfikacji celów strategicznych. Obejmuje on wybór samych wskaźników monitoringu oraz określenie wartości bazowych i docelowych wskaźników (Zintegrowane planowanie, 2013). W procesie monitorowania strategii i projektów zintegrowanych najczęściej wykorzystywane są: 
- wskaźniki produktu - pokazujące bezpośrednio powstałe efekty w wyniku realizacji danego projektu, określa rzeczowe efekty danego działania;

- wskaźniki rezultatu - pokazujące efekty i zmiany powstające bezpośrednio i natychmiastowo;

- wskaźniki oddziaływania (wpływu) - pokazujące pośrednie i długookresowe efekty i konsekwencje realizacji danej strategii/projektu dla rozwoju, oddziaływanie danego projektu na otoczenie gospodarcze, społeczne i przestrzenne.

Równolegle opracowywany zostaje system ewaluacji strategicznej. Jest to ocena wartości realizowanej strategii i projektów zintegrowanych z zastosowaniem określonych kryteriów. Inaczej mówiąc, ewaluacja to systematyczne badanie wartości albo cech konkretnego planu lub projektu, z punktu widzenia przyjętych kryteriów, w celu ich usprawnienia, rozwoju lub lepszego rozumienia. Powinna dostarczać rzetelnych i przydatnych informacji, wspierając proces decyzyjny oraz współdziałanie wszystkich partnerów zaangażowanych w realizację strategii/ projektu (Ekiert, 2004). W klasycznym ujęciu wyróżniamy trzy typy ewaluacji: ewaluację ex ante - przed rozpoczęciem realizacji projektu, ewaluację mid-term - średniookresową oraz ewaluację ex post, przeprowadzaną po zakończeniu realizacji projektu/programu.

Kluczowym elementem ewaluacji jest dobór kryteriów oceny. Najczęściej stosowanymi w praktyce kryteriami są: trafność/adekwatność (ocena, w jakim stopniu przyjęte cele projektu odpowiadają zidentyfikowanym problemom $\mathrm{w}$ obszarze objętym projektem i/lub realnym potrzebom beneficjentów), efektywność (ocena poziomu „ekonomiczności” projektu, czyli stosunek poniesionych nakładów do uzyskanych wyników), skuteczność (ocena do jakiego stopnia cele przedsięwzięcia zdefiniowane na etapie programowania zostały osiągnięte). Typowym kryterium oceny jest także identyfikacja oddziaływania/wpływu (ocena, w jakim stopniu korzyści odniesione przez docelowych beneficjentów miały wpływ na większą populację $\mathrm{w}$ danym sektorze czy regionie) oraz identyfikacja trwałości efektów (ocena efektów po zakończeniu finansowania zewnętrznego i wpływu tego projektu w dłuższym okresie na procesy rozwoju na poziomie sektora, regionu czy kraju) (Ciężka, 2005).

\subsection{Problemy i wyzwania $w$ budowaniu zintegrowanych planów rozwoju - polskie doświadczenia}

Zintegrowane planowanie rozwoju zyskuje coraz większą aprobatę wśród władz samorządowych. Zarówno na poziomie lokalnym, jak i subregionalnym tworzone są plany i projekty zintegrowane. Dotychczasowa wiedza i doświadczenie pozwalają na wskazanie głównych ograniczeń i wyzwań w planowaniu terytorialno-funkcjonalnym. Są to przede wszystkim bariery systemowe, świadomościowe i metodologiczne. 
Bariery administracyjno-instytucjonalne (systemowe) wynikają z braku rozwiązań prawnych dla zintegrowanego systemu planowania i realizacji projektów zintegrowanych oraz mocno utrwalonej hierarchicznej i sektorowej organizacji administracji publicznej, faworyzujące tradycyjne rozwiązania i podejścia w planowaniu rozwoju. Kluczowe problemy to:

- słabość narzędzi motywujących do tworzenia zintegrowanych strategii i projektów rozwojowych (np. instrumentów finansowych);

- ułomność lub brak podstaw prawnych do tworzenia partnerstwa i współpracy dla planowania zintegrowanego (konsultacji społecznych, negocjacji i zaangażowania społeczności w tworzenie planów).

Bariery mentalne i świadomościowe wynikają ze specyfiki działania sektora publicznego. Kluczową rolę odgrywa:

- dominacja rutyny, stereotypowych działań i zachowań w samorządach;

- obawa przed nowością - niepewność procedur, efektów, brak doświadczeń w realizacji zintegrowanych planów;

- niechęć do współpracy - dominacja indywidualistycznych postaw, brak zaufania, nieumiejętność działania w partnerstwie, niedostrzeganie korzyści wynikających ze współpracy;

- konieczność zmiany perspektywy myślenia o procesach rozwoju, wyjście poza „własne podwórko”.

Bariery metodologiczne i informacyjne wynikają ze słabości metod i procedur planistycznych oraz słabości wiedzy o procesach rozwoju w układach funkcjonalnych. Problemy te są głównie pochodną istniejącego systemu statystyki, bazującego na jednostkach administracyjnych, co istotnie utrudnia ocenę procesów rozwojowych, identyfikację zasobów specyficznych czy uchwycenie relacji sieciowych w obszarze funkcjonalnym. Główne problemy to:

- różne metody i przekroje pozyskiwania i gromadzenia danych statystycznych przez różne instytucje publiczne;

- brak w systemie statystyki publicznej danych umożliwiających identyfikowanie zasobów oraz rzeczywistej siły powiązań i współzależności dla obszarów funkcjonalnych;

- brak studiów i retrospektywnych analiz prowadzonych dla obszarów funkcjonalnych utrudniających delimitację obszarów funkcjonalnych;

- słabość strategicznego myślenia wynikająca z konieczności „wyjścia” poza granice administracyjne jednostki terytorialnej;

- trudności w analizowaniu zjawisk w układach funkcjonalnych wynikające ze zmiany poziomu analizy (ang. modifiable area unit problem - MAUP);

- konieczność przełamywania stereotypów i rutyn wśród ekspertów i planistów;

- słabo spopularyzowana wiedza o dobrych praktykach, przykładach i doświadczeniach w tworzeniu planów zintegrowanych. 


\section{Podsumowanie}

Terytorialnie ukierunkowana polityka rozwoju wpisuje się w mechanizmy zorientowane na inteligentny, trwały i zrównoważony rozwój, sprzyjający włączeniu społecznemu, określony w ramach Strategii Europa 2020. Podkreśla ona konieczność koordynacji i zwiększenia skuteczności podejmowanych działań na rzecz budowania konkurencyjności i spójności europejskiej przestrzeni, w wymiarze lokalnym i regionalnym. Wskazuje na kluczową rolę współzarządzania terytorialnego (territorial governance) rozumianego jako intensywny i stały dialog pomiędzy wszystkimi aktorami rozwoju terytorialnego działającymi w sektorze gospodarczym, organizacjach pozarządowych, sektorze publicznym czy środowisku naukowym.

Podejście ukierunkowane terytorialnie od wielu lat stosowane jest z powodzeniem w różnych krajach Europy, w wielu przypadkach bez świadomego określania go jako takiego (Ministry of Regional Development, 2013). Okazało się ono efektywne w zwiększaniu skuteczności działań na rzecz rozwoju między innymi poprzez uwolnienie niewykorzystywanego potencjału na szczeblu lokalnym, miejskim i regionalnym. $Z$ doświadczeń wielu krajów wynika, iż sprzyja ono budowaniu spójności terytorialnej i wykorzystaniu kapitału terytorialnego, a tym samym zwiększa własne zasoby poszczególnych regionów i stymuluje oddolne procesy rozwojowe. Nowy paradygmat polityki rozwoju eksponuje ważność różnorodności lokalnej i regionalnej jako istotnej wartości w rozwoju. Umożliwia ono zwiększenie elastyczności polityk publicznych w odniesieniu do specyfiki określonego terytorium. Podkreśla potrzebę zintegrowanego podejścia do rozwiązywania problemów, różnicowania narzędzi polityki i ich dostosowania do warunków lokalnych wraz z wykorzystaniem nowoczesnego wielopoziomowego współrządzenia (multi-level governance).

\section{Bibliografia}

Barca F. (2009), An Agenda for a Reformed Cohesion Policy. A place-based approach to meeting European Union challenges and expectations, Independent Report prepared at the request of Danuta Hübner, Commissioner for Regional Policy.

Boschma R. A. (2005), Proximity and innovation: a critical assessment, Regional Studies, Vol. 39.1, s. 68 .

Camagni R. (2011), Local knowledge, national vision: challenge and prospect for the UE regional policy, [w:] Territorial Dimension of Development Policies, Ministry of Regional Development, Warsaw.

Chądzyński J., Nowakowska A., Przygodzki Z. (2008), Region i jego rozwój w warunkach globalizacji, Wydawnictwo CeDeWu, Warszawa.

Ciężka B. (red.) (2005), Ewaluacja kwestie ogólne, Wydawnictwo Polskiego Towarzystwa Ewaluacyjnego, Warszawa. 
Dziemianowicz W., Szmigiel-Rawska K., Nowicka P., Dąbrowska A. (2012), Planowanie strategiczne. Poradnik dla pracowników administracji publicznej, MRR, Warszawa.

Ekiert K. (2004), Ewaluacja w administracji publicznej-funkcje, standardy $i$ warunki stosowania, Rządowe Centrum Studiów Strategicznych, Warszawa.

Grzeszczak J. (1999), Bieguny wzrostu a formy przestrzeni spolaryzowanej, Prace Geograficzne Instytutu Geografii i Przestrzennego Zagospodarowania PAN, nr 173, Wydawnictwo Continuo, Wrocław, s. 56-58.

Jewtuchowicz A. (2005), Terytorium i wspótczesne dylematy jego rozwoju, Wydawnictwo Uniwersytetu Łódzkiego, Łódź.

Karta Lipska na rzecz zrównoważonego rozwoju miast europejskich, Lipsk 2007.

Markowski T. (2013), Elastyczne i zintegrowane planowanie w obszarach funkcjonalnych $-w$ stronę nowego podejścia do planowania przestrzennego, Poznań.

Ministerstwo Administracji i Cyfryzacji (2012), Praktyczne aspekty budowy systemu Regionalnych Obserwatoriów Terytorialnych, Warszawa, http://www.mir.gov.pl/aktualnosci/polityka_rozwoju/Strony/Inauguracyjne_posiedzenie_KOT_160512.aspx

Ministerstwo Infrastruktury i Rozwoju (2012), Kontrakt terytorialny. W kierunku negocjacyjnego systemu programowania działań rozwojowych ukierunkowanych terytorialnie. Zasady funkcjonowania kontraktu terytorialnego w latach 2014-2020, Warszawa, www.mir.gov.pl/Kontrakt_zasady_dzialania_03_08_FIN.pdf.

Ministerstwo Infrastruktury i Rozwoju (2013a), Zasady realizacji Zintegrowanych Inwestycji Terytorialnych $w$ Polsce, Warszawa, www.mir.gov.pl

Ministerstwo Infrastruktury i Rozwoju (2013b), Zintegrowane podejście ukierunkowane terytorialnie, Warszawa.

Ministerstwo Rozwoju Regionalnego (MRR) (2010), Krajowa Strategia Rozwoju Regionalnego 2010-2020: Regiony, Miasta, Obszary wiejskie, Warszawa.

Ministerstwo Rozwoju Regionalnego (2011a), Przewodnik aktualizacji strategii rozwoju województw, Warszawa.

Ministerstwo Rozwoju Regionalnego (2011b), Zarządzenie Ministra Rozwoju Regionalnego z dnia 21 marca 2011 w sprawie powołania Krajowego Forum Terytorialnego, https://www.mir.gov. $\mathrm{pl} / . .$. Krajowe_Forum_Terytorialne/.../zarzadzenie.pdf.

Ministerstwo Rozwoju Regionalnego (2012a), System monitorowania polityk publicznych w ujęciu terytorialnym opartym o system krajowych i regionalnych obserwatoriów terytorialnych, Warszawa, pl/rozwoj_regionalny/Ewaluacja_i_analizy/Krajowe_Obserwatorium_Terytorialne

Ministerstwo Rozwoju Regionalnego (MRR) (2012b), Koncepcja Zagospodarowania Przestrzennego Kraju 2030, http://www.mir.gov.pl/rozwoj_regionalny/polityka_przestrzenna/kpzk/strony/ koncepcja_przestrzennego_zagospodarowania_kraju.aspx

Ministry of Regional Development (2011), Territorial dimension of EU Policie. Strategic programming, coordination and institutions territorially-sensitive for an efficient delivery of the new growth agenda, Warsaw.

Ministry of Regional Development (2013), Place-based territorially sensitive and integrated approach, Warsaw.

Nowakowska A. (2011), Regionalny wymiar procesów innowacji, Wydawnictwo Uniwersytetu Łódzkiego, Łódź.

Nowakowska A. (2013), Od regionu do terytorium - od planowania strategicznego do planowania zintegrowanego (materiał roboczy), Łódź.

Pecqueur B. (2000), Le developpement local pour une economie des territoires, Syros, Paris, s. 132.

Pietrzyk I. (2004), Globalizacja, integracja europejska a rozwój regionalny, [w:] A. Jewtuchowicz (red.), Wiedza, innowacyjność, przedsiębiorczość a rozwój regionów, Wydawnictwo Uniwersytetu Łódzkiego, Łódź, s. 12-13. 
Ratuszniak I. (2013), Realizacja Zintegrowanych Inwestycji Terytorialnych w Polsce, Wrocław, www.mir.gov.pl

Regulski A. (2012), Powiązania SRW z systemem kontraktu terytorialnego, Krajowe Forum Terytorialne, Instytut Badań Strukturalnych, Warszawa, https://www.mir.gov.pl/rozwoj_regionalny/ Polityka_rozwoju/System_zarzadzania_rozwojem

Szlachta J., Zaucha J. (2012), For an enhanced territorial dimension of the Cohesion Policy in Poland in the 2014-2020 period, Instytut Rozwoju (dokument roboczy).

Szlachta J., Zaucha J. (2015), Wzmacnianie terytorialnego wymiaru polityki spójności w Polsce w latach 2014-2020, Wydawnictwo Uniwersytetu Ekonomicznego w Katowicach, Katowice.

Tölle A. (2014), Zintegrowane formy planowania i zarzadzania rozwojem lokalnym a instrumentarium planistyczne. System polski na tle systemu niemieckiego, „Studia Regionalne i Lokalne”, nr $3(57) / 2014$.

Zintegrowane planowanie (2013), Materiały szkoleniowe w projekcie „Systemowe wsparcie procesów zarządzania w JST".

\section{INTEGRATED DEVELOPMENT PLANS - TOWARDS TERRITORIAL-FUNCTIONAL APPROACH TO THE DEVELOPMENT OF A TERRITORIAL UNIT}

\section{(Summary)}

A new interpretation of the meaning of space in the processes of economic development (i.e. the territorial development paradigm) has led to the reinterpretation of the ways of pursuing the development policy at the local / regional level. The foundation of this paradigm of creating development policy is also a powerful critique of the existing methods of stimulating the development made at the beginning of a new programming period. It showed the inefficiency and ineffectiveness of the cohesion policy, both in terms of building cohesion and competitiveness of the European community. In response to these problems, an attempt to reform the methods and ways of stimulating the development in European, regional and local dimension has been made. Embodiment of these reforms is the territorial and functional approach to creating development policy (place based policy). This approach aims at the greater consideration of different conditions of development and optimal use of endogenous resources (i.e. the territorial capital) in the dynamization of development processes. It emphasizes the need for change in the method of strategic planning of the development of territorial units and creating the so-called integrated plans.

Presented considerations directly affect the new paradigm of planning and the creation of territorial development. The author embeds her deliberations in the processes of territorial development to interpret the essence of an integrated development policy on the basis of such a specific theoretical foundation. In further analyzes, attention is focused on new instruments of the territorialisation of development policy identified within the Committee for Spatial Economy and Regional Planning. The quintessence of the considerations is to show the nature and stages of the development of integrated strategic plans at the local level. The author shows the difference and specificity of the integrated planning process. The discussion ends with the identification of barriers and challenges in the implementation of the integrated plans, indicating the areas of overcoming stereotypes in Polish realities of self-governments.

Key words: territory, integrated planning, territorial development policy, integrated development strategies. 